\title{
Pengaruh Lokasi Sumber Rizobakteri Terhadap Daya Hambat Pertumbuhan Koloni (Phytophthora palmivora) Patogen Penyebab Busuk Buah Kakao (Theobroma cacao L.) Secara In Vitro
}

\author{
The Effect Of Source Rizobacteria On The Inhibitory Power Of Growth Colony \\ (Phytophthora palmivora) Pathogens Causes Of In Vitro Rotten Cocoa Fruit \\ (Theobroma cacao L.)
}

\author{
Ricka Rizkiana $^{1}$, Tjut Chamzurni ${ }^{2}$, Syamsuddin ${ }^{1^{*}}$ \\ ${ }^{1}$ Jurusan Agroteknologi, Fakultas Pertanian, Universitas Syiah Kuala \\ 2 Jurusan Proteksi Tanaman, Fakultas Pertanian, Universitas Syiah Kuala
}

\begin{abstract}
Abstrak. Penelitian ini bertujuan untuk mengetahui pengaruh lokasi sumber isolat rizobakteri terhadap daya hambat pertumbuhan koloni patogen penyebab busuk buah kakao secara in vitro. Penelitian ini dilaksanakan di Laboratorium Ilmu dan Teknologi Benih Jurusan Agroteknologi, Fakultas Pertanian, Universitas Syiah Kuala Darussalam Banda Aceh dari bulan September sampai November 2018, menggunakan Rancangan Acak Lengkap non faktorial. Faktor yang diamati yaitu jumlah isolat rizobakteri yang berpotensi dalam mengahambat pertumbuhan koloni patogen penyebab busuk buah kakao dari dua lokasi pengambilan yang berbeda yaitu dari Tripa dan Gleumpang Minyeuk dengan 3 kali ulangan pada tiap perlakuan yang dilanjutkan dengan Uji Beda Nyata Jujur pada taraf 5\% pada hasil uji F yang signifikan. Hasil penelitian ini menunjukkan pengambilan rizobakteri dari dua lokasi yang berbeda berpengaruh sangat nyata terhadap daya hambat pertumbuhan koloni patogen penyebab busuk buah kakao, yang dijumpai pada perlakuan isolat rizobakteri GM $8 / 2$ dengan daya hambat $58,23 \%$ dan GM $8 / 3$ dengan daya hambat 51,59\% dengan aktifitas penghambat sedang. Juga berpengaruh sangat nyata terhadap laju penghambat pertumbuhan koloni patogen penyebab busuk buah kakao yang dijumpai pada perlakuan isolat rizobakteri TRI 4/7 dengan rerata laju penghambatan 4,76 mm/hari. Isolat rizobakteri yang mampu dalam melarutkan fosfat dijumpai pada perlakuan TRI 3/11, TRI 4/6, TRI 6/14, TRI 7/4, TRI 8/2, TRI 8/4, TRI 8/8, TRI 8/9, GM 3/6, GM 5/6, GM 6/1, GM 6/5, GM 7,/9, GM 8/3, GM 8/8 dan GM 8/11.
\end{abstract}

Kata kunci : agen antagonis, rizobakteri, Phytophthora palmivora

Abstract. This study aims to determine the effect of the location sources of rhizobacterial isolates on the inhibitory power of growth of pathogens causing cocoa fruit rot by in vitro method. This research was carried out at the Seed Science and Technology Laboratory of the Department of Agrotechnology, Faculty of Agriculture, Syiah Kuala Darussalam University Banda Aceh from September to November 2018, used a non factorial Completely Randomized Design. The factors observed were the number of rhizobacterial isolates which had the potential to inhibit the growth of pathogens causing cacao fruit rot from two different locations, namely Tripa and Gleumpang Minyeuk with 3 Repeat times for each treatment were followed by an Honest Real Difference Test at the level of $5 \%$ on a significant $\mathrm{F}$ test result. The results of this study indicate rhizobacterial uptake from two different locations had a very significant effect on the growth inhibitory power of cacao rotten pathogenic colonies, which was found in the treatment of GM 8/2 rhizobacterial isolates with inhibition of $58.23 \%$ and GM $8 / 3$ with inhibitory power $51.59 \%$ with moderate inhibiting activities. It also has a very significant effect on the rate of growth of the inhibitor of cacao rotten fruit pathogens found in the treatment of TRI 4/7 rhizobacterial isolates with an average inhibition rate of $4.76 \mathrm{~mm} /$ day. Rhizobacterial isolates capable of dissolving phosphate were found in the treatment of TRI 3/11, TRI 4/6, TRI 6/14, TRI 7/4, TRI 8/2, TRI 8/4, TRI 8/8, TRI 8/9, GM 3/6, GM 5/6, GM 6/1, GM 6/5, GM 7, 9, GM 8/3, GM 8/8 and GM 8/11.

Keyword : antagonist agent, rhizobacteria, Phytophthora palmivora

Corresponding author: syamsuddin@unsyiah.ac.id

Jurnal Ilmiah Mahasiswa Pertanian - AGT, Vol. 4, No. 2, Mei 2019: 11-20 


\section{PENDAHULUAN}

Kakao (Theobroma cacao L.) merupakan komoditi perkebunan yang sangat berperan penting bagi perekonomian nasional, khususnya sebagai penyedia lapangan kerja, sumber pendapatan dan devisa negara. Tanaman kakao di Indonesia dibudidayakan oleh perkebunan swasta, negara, maupun perkebunan rakyat. Luas lahan perkebunan kakao Indonesia pada tahun 2013 mencapai 1.740 .612 ha dengan produksi mencapai 720.862 ton/ha dan mengalami penurunan pada tahun 2015 mencapai 661.243 ton/ha (Ditjenbun, 2016). Hal serupa juga terjadi disejumlah wilayah di Provinsi Aceh misalnya Nagan Raya dan Pidie. luas area perkebunan Kakao di Pidie pada tahun 2012 mencapai $10.150 \mathrm{Ha}$ dengan hasil produksi mencapai 4.499 ton dan mengalami penurunan yang signifikan yaitu dari menjadi 2.674 ton pada tahun 2013. Begitu juga yang terjadi daerah Nagan raya pada tahun 2012 luas area perkebunan kakao mencapai 5.405 Ha dengan produksi mencapai 1.335 ton namun mengalami penurunan produksi pada tahun 2013 menjadi 1.327 ton (Badan Pusat Statistik Provinsi Aceh, 2013). Penurunan produktivitas kakao menunjukkan bahwa praktik budidaya tanaman kakao mengalami permasalahan baik dari segi lahan, kualitas bibit tanaman kakao serta pengaruh serangan hama dan penyakit tanaman kakao yang menyebabkan penurunan hasil produksi tanaman kakao.

Beberapa penyakit dapat menyerang tanaman kakao akan tetapi penyakit yang sangat penting dan penyebarannya sangat luas adalah penyakit busuk buah (pod rot) yang disebabkan oleh jamur dari genus Phytophthora (Darmono et al., 2006). Secara umum kehilangan hasil akibat penyakit busuk buah Phytophthora (pod rot) dapat mencapai 90\% terutama pada musim hujan (Rosmana et al., 2010). Patogen ini dapat menginfeksi buah, daun, batang, dan akar yang menyebabkan penyakit pada bibit kakao. Penyakit ini dapat menyebabkan daun-daun menjadi kering dan kematian bibit terutama pada tanaman kakao yang berumur 1-2 bulan (McMahon \& Purwantara, 2004). Buah yang terinfeksi akan menjadi busuk total dalam waktu sekitar 2 minggu, tergantung umur buah pada saat terinfeksi (Jackson \& Wright, 2001).

Alternatif pengendalian penyakit busuk buah $P$. palmivora yang dapat dgunakan untuk pengendalian penyakit busuk buah kakao yaitu dengan menggunakan agen hayati bakteri tanah (rizobakteri). Rizobakteri merupakan kelompok bakteri menguntungkan yang agresif 'menduduki' (mengkolonisasi) rizosfir (lapisan tanah tipis antara 1-2 mm di sekitar zona perakaran).

Menurut beberapa penelitian terdahulu penggunaan rizobakteri sebagai agen antagonis mampu menekan pertumbuhan beberapa panyakit yang disebabkan oleh patogen. Seperti penelitian Sutariati dan Wahap (2010) yang menunjukkan bahwa dari 5 lokasi isolat rizobakteri yang diagunakan 4 diantaranya dinyatakan mampu dalam menghambat pertumbuhan patogen Collectrotichum capsici dan Fusarium oxysporum secara in vitro. Maka dari itu penelitian ini dilakukan untuk melihat pengaruh lokasi sumber isolat rizobakteri sebagai agen antagonis dalam menghambat pertumbuhan koloni Phytopthora palmivora patogen penyebab busuk buah kakao secara in vitro.

\section{BAHAN DAN METODOLOGI PENELITIAN}

Penelitian ini dilaksanakan di Laboratorium Ilmu dan Teknologi Benih Jurusan Agroteknologi, Fakultas Pertanian, Universitas Syiah Kuala, Darussalam Banda Aceh. Pelaksanaan penelitian dimulai dari September sampai November 2018. 
Bahan-bahan yang dipakai berupa: sampel buah kakao yang terinfeksi penyakit $P$. palmivora, media PDA, media SPA, alkohol, plastik tahan panas, natrium hipoklorit, aquades, aluminium foil, plastik wrap, dan spiritus. Alat yang digunkan antara lain cawan petri, spatula, tabung reaksi, erlenmayer, oven listrik, lampu bunsen, pipet ukur, timbangan analitik, jarum ose, autoclave, mikroskop, vortex, inkubator, laminar air flow, dan ayakan 9 mesh.

Sampel tanah dikumpulkan dari daerah rizosfer tanaman kakao yang sehat diantara tanaman kakao yang sakit dari dua lokasi Perkubunan Kakao yang berbeda yaitu Desa Kuala Tripa Kecamatan Tripa Kabupaten Nagan Raya dan Desa Amod Mesjid Kecamatan Gleumpang Minyeuk Kabupaten Pidie, begitu juga dengan pengambilan buah kakao yang terinfeksi penyakit $P$. palmivora.

\section{Isolat Rizobakteri}

Isolat rizobakteri diperoleh dari hasil pengenceran secara berseri tanah rizosfer tanaman kakao sehat diantara tanaman kakao yang sakit dari dua tempat yang berbeda yang dilaksankan di Laboratorium. Sebelum di lakukan pengenceran sampel tanah yang telah diambil pada 5 titik di masing-masing lokasi (masing-masing $1 \mathrm{~kg}$ ) di kering anginkan kemudian dihaluskan dengan cara ditumbuk dan disaring menggunakan saringan 9 mesh.

Pengenceran dilakukan dalam tabung reaksi yang berisikan $10 \mathrm{ml}$ aquades steeil dan 1 gram sampel tanah. Siapkan 8 tabung reaksi berisikan aquades steril sebanyak $9 \mathrm{ml}$. Tabung reaksi yang berisikan tanah dan aquades dihomogenkan menggunakan vortex, dari tabung reaksi tersebut ambil $1 \mathrm{ml}$ suspensi dan masukkan kedalam tabung reaksi pertama secara aseptis dengan pipet ukur, yang kemudian disebut sebagai pengenceran pertama $\left(10^{-1}\right)$. Pemindahan suspensi dilanjutkan sampai tingkat pengenceran ke delapan $\left(10^{-8}\right)$. Masingmasing suspensi pengenceran $10^{-3}, 10^{-4}, 10^{-5}, 10^{-6}, 10^{-7}$, dan $10^{-8}$ ditanam pada media SPA dalam cawan petri dengan mengambil $0,1 \mathrm{ml}$ suspensi menggunakan pipet ukur. Koloni rizobakteri yang tumbuh selanjutnya disubkulturkan sebanyak 3 kali untuk mendapatkan isolat murni

\section{Isolat Patogen Phytopthora palmivora}

Isolasi patogen $P$. palmivora didapat dari pengambilan buah kakao yang terinfeksi $P$. palmivora yang kemudian di isolasi di Laboratorium dengan memotong kecil-kecil bagian sampel buah kakao yang terinfeksi. Kemudian bahan isolasi direndam menggunakan hypoklorit $2 \%$ selama 10 menit sebagai desinfektan, lalu dicuci menggunakan aquadest sebanyak 3 kali. Potongan buah kakao dikulturkan dalam cawan petri steril berdiameter $9 \mathrm{~cm}$ yang berisikan media PDA dan di inkubasi \pm 7 hari, dengan suhu ruang $26^{\circ} \mathrm{C}-29^{\circ} \mathrm{C}$. Satu cawan petri berisikan 4 potongan isolasi buah kakao. Koloni patogen yang telah tumbuh, disubkulturkan sebnyak 3 kali untuk memperoleh isolat patogen murni. Kemudian disimpan secara berskala dan waktu diperlukan dilakukan peremajaan.

\section{Media PDA}

Pada penelitian ini media PDA yang digunakan adalah median PDA siap pakai (produksi HIMEDIA) dengan komposisi 39 gram untuk 1 liter aquades steril. Larutan PDA disterilkan di dalam autoclave suhu $121^{\circ} \mathrm{C}-124^{\circ} \mathrm{C}$ yang dipertahankan selama 15 menit. Kemudian dibiarkan hingga suhunya turun menjadi hangat dan siap dituangkan ke dalam cawan petri dan diletakkan dalam Laminar Air Flow hingga agarnya memadat dan siap digunakan. 


\section{Media SPA}

Media SPA merupakan media yang baik untuk pertumbuhan beberapa jenis bakteri tanaman. Bahan yang digunakan dalam pembuatan media SPA yaitu Sukrosa 20 gram, Pepton 5 gram, $\mathrm{K}_{2} \mathrm{HPO}_{4}$ 0,5 gram, $\mathrm{MgSO}_{4} .7 \mathrm{H}_{2} \mathrm{O} 0,25$ gram, dan agar-agar 12 gram, semua bahan dihomogenkan dalam erlenmayer yang beriskan 1 liter aqudes steril, setelah semua bahan larut disterilkan pada suhu $121^{\circ} \mathrm{C}$ menggunakan aotoclave dan diperthankan selama 15 menit lalu siap dituangkan kedalam petridis. Setelah agar memadat, media siap digunakan.

\section{Uji Daya Hambat Rizobakteri terhadap Patogen}

Uji ini merupakan metode seleksi tahap awal untuk mendapatkan isolat yang berpotensi sebagai agen antagonis. Uji antagonis isolat rizobakteri terhadap koloni patogen dilakukan pada media PDA dengan meletakkan potongan isolat patogen ukuran 0,5 cm ditengan cawan petri dan 4 isolat rizobakteri lainnya dengan jarak 2,25 cm dengan isolat patogen. Kemudian isolat rizobakteri yang memenuhi kriteria sebagai agen antagonis di uji lagi dengan metode kultur ganda.

Pengujian metode kultur ganda dilakukan pada cawan petri berdiameter $9 \mathrm{~cm}$ yang berisikan media PDA. Jarak inokulasi antara patogen dan rizobakteri yaitu $3 \mathrm{~cm}$. Pengujian diinkubasi pada suhu ruang $\left(28^{\circ} \mathrm{C}-29^{\circ} \mathrm{C}\right)$. Untuk masing-masing isolat rizobakteri dilakukan pengujian dengan pengulangan 3 kali. Pengamatan dilakukan setiap hari sampai 7 hari terhadap pertumbuhan patogen dengan mengukur jari-jari pertumbuhan patogen menjauhi rizobakteri $\left(\mathrm{R}_{1}\right)$, dan jari-jari pertumbuhan patogen kearah rizobakteri $\left(\mathrm{R}_{2}\right)$. Selanjutnya data yang diperoleh digunakan untuk menghitung persentase daya hambat (DH) isolat rizobakteri terhadap patogen, yang di tentukan dengan rumus :

$$
D H=\frac{\left(R_{1}-R_{2}\right)}{R_{2}} \times 100 \%
$$

Daya hambat rizobakteri terhadap patogen diklasifikasikan berdasarkan skala persen sebagai berikut : aktivitas sangat tinggi $(++++=>75 \% \mathrm{DH})$, aktivitas tinggi $(+++=61 \%-75 \%$ $\mathrm{DH})$, aktifitas sedang $(++=51 \%-65 \% \mathrm{DH})$, aktivitas rendah $(+=\leq 50 \% \mathrm{DH})$.

\section{Uji Laju Penghambatan Pertumbuhan Koloni}

Laju penghambatan pertumbuhan koloni patogen merupakan kecepatan rizobakteri dalam menghambat pertumbuhan patogen yang diamati setiap hari sampai 7 hari terhadap panjang diameter koloni patogen pada pengaman ke-i $\left(\mathrm{X}_{\mathrm{i}}\right)$, dan waktu pengamatan yang dinyatakan dalam hari ke-i $\left(\mathrm{T}_{\mathrm{i}}\right)$. Kemudian data yang diperoleh digunakan untuk menghitung laju penghambatan pertumbuhan koloni (LPPK) isolat rizobakteri terhadap patogen, yang ditentukan dengan rumus :

$$
\mathbf{L P P K}={ }_{\mathbf{0}}^{\mathbf{7}}\left[\frac{(X i-X i)-1}{T i}\right] \mathrm{mm} / \mathrm{hari}
$$

\section{Karakteristik Morfologi Rizobakteri}

Karakteristik morfologi dari rizobakteri sebagai agen antagonis yang diamati meliputi bentuk permukaan koloni, warna koloni dan bentuk pinggiran koloni. Warna koloni bakteri yang sering muncul yaitu warna putih kekuning-kuningan, merah muda, coklat, hijau, ungu, dan biru. Bentuk permukaan koloni diamati secar langsung, koloni yang tumbuh seperti bulat, cekung, dan cembung. Bentuk permukaan koloni juga diamati secara langsung dengan mengamati tepi koloni seperti rata atau tidak rata. 


\section{Kemampuan Rizobakteri dalam Melarutkan Fosfat}

Pengujian kemampuan rizobakteri dalam melarutkan fosfat menggunakan media uji Pikovskaya's agar dengan penambahan tricalcium phosphate (TCP) sebagai sumber fosfat. Komposisi bahan kimia yang digunakan terdiri dari glukosa 10 gram, $\mathrm{NaCl} 0,2$ gram, $\mathrm{KCl}$ 0,2 gram, $\mathrm{MgSO}_{4}$ 0,1 gram, $\mathrm{MnSO}_{4}$ 2,5 gram, $\mathrm{FeSO}_{4}$ 2,5 gram, yeast extract 0,5 gram, $\left(\mathrm{NH}_{4}\right) 2 \mathrm{SO}_{4}$ 0,5 gram, agar 15 gram, dan aquades 1 liter. Media disterilakn dengan autoclave. Media uji dituangkan ke dalam cawan petri berdiameter $9 \mathrm{~cm}$, dibuat lubang dengan cock borrer dan isi dengan 0,2 $\mathrm{ml}$ suspensi isolat rizobakteri yang diuji. Suspensi isolat diinkubasi selama 3-7 hari dalam ruang inkubasi dengan suhu $28^{\circ} \mathrm{C}-29^{\circ} \mathrm{C}$. Kemampuan melarutkan fosfat dievaluasi secara kualitatif berdasarkan terbentuknya halo disekitar lubang yang berisi suspensi rizobakteri

\section{HASIL DAN PEMBAHASAN}

Hasil isolasi rizobakteri yang telah dilakukan terhadap tanah rizosfer tanaman kakao sehat diantara tanaman yang sakit dari dua lokasi yang berbeda didapati sebanyak 128 isolat, 65 isolat dari Tripa (TRI) dan 63 isolat dari Gleumpang Minyeuk (GM). Dari hasil uji antagonis yang telah dilakukan sebanyak 34 isolat rizobakteri dinyatakan memenuhi syarat sebagai agens antagonis yang mana mampu menghambat pertumbuhan koloni patogen P.palmivora. 34 isolat yang berpotensi sebagai agen antagonis dapat dilihat pada Tabel 1 .

Tabel 1. Isolat Rizobakteri yang berpotensi sebagai Agen Antagonis terhadap koloni P.palmivora patogen penyebab busuk buah Kakao

\begin{tabular}{ccccc}
\hline \multicolumn{5}{c}{ Isolat Rizobakteri yang Berpotensi sebagai Agen Antagonis } \\
\hline TRI 3/3 & TRI 6/13 & TRI 8/4 & GM 5/6 & GM 8/2 \\
TRI 3/4 & TRI 6/14 & TRI 8/6 & GM 6/1 & GM 8/3 \\
TRI 3/11 & TRI 6/15 & TRI 8/8 & GM 6/5 & GM 8/8 \\
TRI 4/6 & TRI 7/1 & TRI 8/9 & GM 6/6 & GM 8/9 \\
TRI 4/7 & TRI 7/2 & TRI 8/10 & GM 7/9 & GM 8/10 \\
TRI 4/10 & TRI 7/4 & GM 3/6 & GM 7/10 & GM 8/11 \\
TRI 6/6 & TRI 8/2 & GM 3/7 & GM 8/1 & \\
\hline
\end{tabular}

Keterangan : TRI = Tripa, GM = Gleumpang Minyeuk, $3 / 3$ = pengenceran ke-3/bakteri ke-3

\section{Uji Daya Hambat Pertumbuhan Koloni Patogen P.palmivora}

Dari hasil pengujian yang telah dilakukan, 34 isolat yang diuji menunjukkan kemampuan daya hambat yang berbeda-beda. Isolat rizobakteri yang memiliki daya hambat terbaik dijumpai pada isolat GM 8/2 dengan rerata daya hambat 58,23\%. Rata-rata daya hambat (\%) isolat rizobakteri terhadap pertumbuhan koloni patogen P.palmivora disajikan pada Tabel 2.

Pada tabel diatas menunjukkan bahwa isolat rizobakteri dengan daya hambat terbaik yaitu isolat GM 8/2 berbeda sangat nyata dengan 13 isolat lain yaitu TRI 3/3, TRI 3 /4, TRI 3/11, TRI 4/6, TRI 4/7, TRI 4/10, TRI 6/6, TRI 7/2, TRI 8/2, TRI 8/8, GM 6/1, GM 6/5, dan GM 8/1, namun berbeda tidak nyata dengan 20 isolat rizobakteri lainnya. 
Tabel 2. Rata-rata daya hambat (\%) Isolat Rizobakteri dan aktifitas daya hambat terhadap pertumbuhan koloni patogen P.palmivora pada tanaman Kakao secara In Vitro

\begin{tabular}{|c|c|c|}
\hline \multirow[b]{2}{*}{ Rizobakteri Agen Antagonis } & \multicolumn{2}{|c|}{ Daya Hambat terhadap Patogen $(\%)$} \\
\hline & $\begin{array}{l}\text { Daya Hambat Rizobakteri } \\
(\%)\end{array}$ & $\begin{array}{l}\text { Aktifitas Penghambatan } \\
\text { Rizobakteri }\end{array}$ \\
\hline Isolat TRI 3/3 & 23,03 abcde & + \\
\hline Isolat TRI 3 /4 & $6,90 \mathrm{ab}$ & + \\
\hline Isolat TRI 3/11 & $2,87 \mathrm{a}$ & + \\
\hline Isolat TRI 4/6 & $13,16 \mathrm{abc}$ & + \\
\hline Isolat TRI 4/7 & $2,87 \mathrm{a}$ & + \\
\hline Isolat TRI 4/10 & 17,72 abcd & + \\
\hline Isolat TRI 6/6 & 22,91 abcde & + \\
\hline Isolat TRI 6/13 & 39,88 cdef & + \\
\hline Isolat TRI 6/14 & 39,23 cdef & + \\
\hline Isolat TRI 6/15 & 40,48 cdef & + \\
\hline Isolat TRI 7/1 & 41,16 cdef & + \\
\hline Isolat TRI 7/2 & $14,24 \mathrm{abc}$ & + \\
\hline Isolat TRI 7/4 & 39,88 cdef & + \\
\hline Isolat TRI 8/2 & 24,03 abcde & + \\
\hline Isolat TRI 8/4 & $41,80 \mathrm{cdef}$ & + \\
\hline Isolat TRI 8/6 & 43,38 cdef & + \\
\hline Isolat TRI 8/8 & 26,45 abcde & + \\
\hline Isolat TRI 8/9 & 29,68 abcdef & + \\
\hline Isolat TRI 8/10 & 36,79 bcdef & + \\
\hline Isolat GM 3/6 & $47,66 \mathrm{def}$ & + \\
\hline Isolat GM 3/7 & 32,41 abcdef & + \\
\hline Isolat GM 5/6 & $43,09 \mathrm{cdef}$ & + \\
\hline Isolat GM 6/1 & 21,58 abcde & + \\
\hline Isolat GM 6/5 & 20,88 abcde & + \\
\hline Isolat GM 6/6 & 37,16 bcdef & + \\
\hline Isolat GM 7/9 & 41,79 cdef & + \\
\hline Isolat GM 7/10 & $43,09 \mathrm{cdef}$ & + \\
\hline Isolat GM 8/1 & 25,26 abcde & + \\
\hline Isolat GM 8/2 & $58,23 \mathrm{f}$ & ++ \\
\hline Isolat GM 8/3 & $51,59 \mathrm{ef}$ & ++ \\
\hline Isolat GM 8/8 & 43,73 cdef & + \\
\hline Isolat GM 8/9 & 31,47 abcdef & + \\
\hline Isolat GM 8/10 & 38,45 cdef & + \\
\hline Isolat GM 8/11 & $47,55 \mathrm{def}$ & + \\
\hline
\end{tabular}

BNJ 0,05

31,32

Keterangan : Angka yang diikuti huruf yang sama berbeda tidak nyata pada Uji Beda Nyata Jujur (BNJ) $\alpha=0,05$ Aktifitas sangat tinggi ( $++++=>75 \% \mathrm{DH})$, aktifitas tinggi $(+++=61 \%-75 \% \mathrm{DH})$, aktifitas sedang $(++=51 \%-65 \% \mathrm{DH})$, aktifitas rendah $(+=<50 \% \mathrm{DH})$, dan tidak ada aktifitas $(-)$

\section{Uji Laju Penghambatan Pertumbuhan Koloni Patogen $\boldsymbol{P}$. palmivora}

Hasil pengujian yang telah dilakukan menunjukkan bahwa laju penghambatan isolat rizobakteri berpengaruh sangat nyata terhadap pertumbuhan koloni patogen P.palmivora, perlakuan isolat risobakteri terbaik dijumpai pada isolat TRI 4/7 dengan rerata laju penghambatan $4,76 \mathrm{~mm} /$ hari yang berbeda sangat nyata dengan isolat TRI $8 / 9$, namun berbeda 
tidak nyata dengan 34 isolat rizobakteri lainnya. Rata-rata laju penghambatan pertumbuhan isolat rizobakteri terhadap pertumbuhan koloni patogen P.palmivora disajikan pada Tabel 3.

Tabel 3. Rata-rata Laju penghambatan Pertumbuhan Koloni (LPPK) Isolat Rizobakteri terhadap Pertumbuhan Koloni Patogen P.palmivora pada Tanaman Kakao secara In Vitro

\begin{tabular}{clllll}
\hline & Nama Isolat & LPPK $(\mathbf{m m} / \mathbf{h a r i})$ & & Nama Isolat & LPPK $(\mathbf{m m} / \mathbf{h a r i})$ \\
\hline 1. & Isolat TRI 3/3 & $4,43 \mathrm{ab}$ & 18. & Isolat TRI 8/9 & $3,06 \mathrm{a}$ \\
2. & Isolat TRI 3 /4 & $4,64 \mathrm{~b}$ & 19. & Isolat TRI 8/10 & $3,45 \mathrm{ab}$ \\
3. & Isolat TRI 3/11 & $4,60 \mathrm{~b}$ & 20. & Isolat GM 3/6 & $3,54 \mathrm{ab}$ \\
4. & Isolat TRI 4/6 & $4,52 \mathrm{ab}$ & 21. & Isolat GM 3/7 & $4,16 \mathrm{ab}$ \\
5. & Isolat TRI 4/7 & $4,76 \mathrm{~b}$ & 22. & Isolat GM 5/6 & $3,74 \mathrm{ab}$ \\
6. & Isolat TRI 4/10 & $4,58 \mathrm{~b}$ & 23. & Isolat GM 6/1 & $3,87 \mathrm{ab}$ \\
7. & Isolat TRI 6/6 & $4,46 \mathrm{ab}$ & 24. & Isolat GM 6/5 & $3,94 \mathrm{ab}$ \\
8. & Isolat TRI 6/13 & $4,41 \mathrm{ab}$ & 25. & Isolat GM 6/6 & $3,84 \mathrm{ab}$ \\
9. & Isolat TRI 6/14 & $4,44 \mathrm{ab}$ & 26. & Isolat GM 7/9 & $3,81 \mathrm{ab}$ \\
10 & Isolat TRI 6/15 & $4,27 \mathrm{ab}$ & 27. & Isolat GM 7/10 & $3,80 \mathrm{ab}$ \\
11 & Isolat TRI 7/1 & $4,31 \mathrm{ab}$ & 28. & Isolat GM 8/1 & $3,68 \mathrm{ab}$ \\
12. & Isolat TRI 7/2 & $4,66 \mathrm{~b}$ & 29. & Isolat GM 8/2 & $3,60 \mathrm{ab}$ \\
13. & Isolat TRI 7/4 & $4,35 \mathrm{ab}$ & 30. & Isolat GM 8/3 & $3,44 \mathrm{ab}$ \\
14. & Isolat TRI 8/2 & $4,64 \mathrm{~b}$ & 31. & Isolat GM 8/8 & $3,76 \mathrm{ab}$ \\
15. & Isolat TRI 8/4 & $4,41 \mathrm{ab}$ & 32. & Isolat GM 8/9 & $4,09 \mathrm{ab}$ \\
16. & Isolat TRI 8/6 & $3,49 \mathrm{ab}$ & 33. & Isolat GM 8/10 & $3,90 \mathrm{ab}$ \\
17. & Isolat TRI 8/8 & $3,94 \mathrm{ab}$ & 34. & Isolat GM 8/11 & $3,49 \mathrm{ab}$ \\
& BNJ 0,05 & $\mathbf{1 , 5 1}$ & & BNJ 0,05 & $\mathbf{1 , 5 1}$ \\
\hline
\end{tabular}

Keterangan : Angkat yang diikuti huruf yang sama berbeda tidak nyata pada uji Beda Nyta Jujur (BNJ) $\alpha=0,05$, LPPK = Laju Penghambat Pertumbuhan Koloni

\section{Karakteristik Morfologi rizobakteri}

Karakteristik morfolgi dari rizobakteri yang dibiakkan pada media tumbuh PDA,setelah \pm 4 hari pengamatan menunjukkan bentuk permukaan, warna koloni, dan bentuk pinggiran koloni yang berbeda-beda. Karakteristik morfologi isolat rizobakteri dapat dilihat pada Tabel 4.

Tabel 4. Karakteristik Morfologi Rizobakteri Agen Biokontrol

\begin{tabular}{llll}
\hline $\begin{array}{l}\text { Rizobakteri Agen } \\
\text { Biokontrol }\end{array}$ & $\begin{array}{l}\text { Bentuk Permukaan } \\
\text { Koloni }\end{array}$ & Warna Koloni & $\begin{array}{l}\text { Bentuk Pinggiran } \\
\text { Koloni }\end{array}$ \\
\hline Isolat TRI 3/3 & Rata & Putih & Rata \\
Isolat TRI 3 /4 & Cembung & Kuning & Rata \\
Isolat TRI 3/11 & Cembung & Kuning & Tidak rata \\
Isolat TRI 4/6 & Cembung & Kuning & Tidak rata \\
Isolat TRI 4/7 & Cembung & Kuning & Tidak rata \\
Isolat TRI 4/10 & Cembung & Putih & Tidak rata \\
Isolat TRI 6/6 & Cembung & Putih kekuningan & Rata \\
Isolat TRI 6/13 & Rata & Putih kekuningan & Tidak rata \\
Isolat TRI 6/14 & Rata & Putih bening & Tidak rata \\
Isolat TRI 6/15 & Cembung & Kuning bening & Tidak rata \\
Isolat TRI 7/1 & Rata & Putih bening & Tidak rata \\
Isolat TRI 7/2 & Cembung & Kuning & Tidak rata \\
Isolat TRI 7/4 & Cembung & Putih kekuningan & Tidak rata \\
\hline
\end{tabular}

Pengaruh Lokasi Sumber Isolat Rizobakteri Terhadap Daya Hambat Pertumbuhan Koloni

(Phytopthora palmivora) Patogen Penyebab Busuk Buah Kakao (Threobroma cacao L.) Secara In

Vitro (Ricka Rizkiana, Tjut Chamzurni, Syamsuddin)

Jurnal Ilmiah Mahasiswa Pertanian, Vol. 4, No. 2, Mei 2019: 11-20 


\begin{tabular}{llll}
\hline Isolat TRI 8/2 & Cembung & Putih & Rata \\
Isolat TRI 8/4 & Cembung & Kuning bening & Tidak rata \\
Isolat TRI 8/6 & Rata & Putih bening & Tidak rata \\
Isolat TRI 8/8 & Cembung & Kuning & Tidak rata \\
Isolat TRI 8/9 & Rata & Kuning bening & Tidak rata \\
Isolat TRI 8/10 & Cembung & Kuning bening & Tidak rata \\
Isolat GM 3/6 & Rata & Putih bening & Tidak rata \\
Isolat GM 3/7 & Cembung & Kuning & Tidak rata \\
Isolat GM 5/6 & Cembung & Putih kekuningan & Tidak rata \\
Isolat GM 6/1 & Cembung & Kuning & Tidak rata \\
Isolat GM 6/5 & Cembung & Kuning & Tidak rata \\
Isolat GM 6/6 & Cembung & Putih & Tidak rata \\
Isolat GM 7/9 & Cembung & Putih & Rata \\
Isolat GM 7/10 & Cembung & Putih kekuningan & Tidak rata \\
Isolat GM 8/1 & Rata & Putih bening & Tidak rata \\
Isolat GM 8/2 & Rata & Putih bening & Tidak rata \\
Isolat GM 8/3 & Rata & Kuning brning & Tidak rata \\
Isolat GM 8/8 & Rata & Putih & Tidak rata \\
Isolat GM 8/9 & Cembung & Putih & Tidak rata \\
Isolat GM 8/10 & Rata & Putih bening & Tidak rata \\
Isolat GM 8/11 & Rata & Kuning bening & Tidak rata \\
\hline
\end{tabular}

\section{Uji Kemampuan Rizobakteri dalam Melarutkan Fosfat}

Dari 34 isolat yang diuji, masing-masing rizobakteri memiliki kemampuan yang berbeda-beda dalam melarutkan fosfat. 16 dari isolat tersebut dinyatakan mampu dalam melarutkan fosfta, yaiti isolat TRI 3/11, TRI 4/6, TRI 6/14, TRI 7/4, TRI 8/2, TRI 8/4, TRI 8/9, GM 3/6, GM 5/6, GM 6/1, GM 6/5, GM 7/9, GM 8/3, Gm 8/8, dan GM 8/11 ditandai dengan terbentuknya hallo disekitar media yang diuji. Sedangkan 18 isolat lainnya dinyatakan tidak mampu dalam melarutkan fosfat.

Tabel 5. Kemampuan Rizobakteri dalam melarutkan Fosfat

\begin{tabular}{llllll}
\hline & Nama Isolat & $\begin{array}{l}\text { Kemampuan Melarutkan } \\
\text { Fosfat }\end{array}$ & Nama Isolat & $\begin{array}{l}\text { Kemampuan } \\
\text { Melarutkan Fosfat }\end{array}$ \\
\hline 1. & Isolat TRI 3/3 & - & 18. & Isolat TRI 8/9 & + \\
2. & Isolat TRI 3 /4 & - & 19. & Isolat TRI 8/10 & - \\
3. & Isolat TRI 3/11 & + & 20. & Isolat GM 3/6 & + \\
4. & Isolat TRI 4/6 & + & 21. & Isolat GM 3/7 & - \\
5. & Isolat TRI 4/7 & - & 22. & Isolat GM 5/6 & + \\
6. & Isolat TRI 4/10 & - & 23. & Isolat GM 6/1 & + \\
7. & Isolat TRI 6/6 & - & 24. & Isolat GM 6/5 & + \\
8. & Isolat TRI 6/13 & - & 25. & Isolat GM 6/6 & - \\
9. & Isolat TRI 6/14 & + & 26. & Isolat GM 7/9 & + \\
10. & Isolat TRI 6/15 & - & 27. & Isolat GM 7/10 & - \\
11. & Isolat TRI 7/1 & - & 28. & Isolat GM 8/1 & - \\
12. & Isolat TRI 7/2 & - & 29. & Isolat GM 8/2 & - \\
13. & Isolat TRI 7/4 & + & 30. & Isolat GM 8/3 & + \\
14. & Isolat TRI 8/2 & + & 31. & Isolat GM 8/8 & + \\
15. & Isolat TRI 8/4 & + & 32. & Isolat GM 8/9 & - \\
16. & Isolat TRI 8/6 & - & 33. & Isolat GM 8/10 & - \\
17. & Isolat TRI 8/8 & + & 34. & Isolat GM 8/11 & + \\
\hline
\end{tabular}

Keterangan : (+) = Mampu Melarutkan fosfat, $(-)=$ Tidak Mampu Melarutkan Fosfat 
Berdasarkan hasil pengamatan yang didapat, dari hasil pengambilan sampel tanah rizosfer sebagai sumber isolat rizobakteri isolat GM 8/2 menunjukkan daya hambat terbaik dalam menekan pertumbuhan koloni patogen P.palmivora, sedangkan untuk hasil laju penghambat pertumbuhan koloni P.palmivora isolat terbaik di jumpai pada isolat TRI 4/7. Hasil penelitian Syamsuddin et al. (2006) menunjukkan bahwa hasil uji in vitro rizobakteri jenis Bacillus coagulas BSTL35, yang diisolasi dari rizosfer tanaman cabai mampu dalam menghambat pertumbuhan koloni $P$. capsici hingga $76,90 \%$ dan rizobakteri jenis S.marcescens SSCN04 mampu menghambat di atas 50\%.

Hasil penelitian Aulia et al., (2017) menunjukkan bahwa perlakuan biopriming pada benih cabai dengan kombinasi isolat rizobakteri $\mathrm{E} 1+\mathrm{F} 2 \mathrm{~B} 1$ dapat menurunkan kejadian penyakit busuk Phytopthora dari 13,3\% (kontrol positif) menjadi 6,1\% pada 5 HSI tanah inokulum P.capsici.

Hasil penelitian Dyah et al. (2015) menunjukkan dari keseluruhan isolat rizobakteri yang diujikan memiliki persentase daya hambat yang tinggi terhadap pertumbuhan $P$. capsici setelah 8 hari diinkubasi, yakni rizobakteri CM8, rizobakteri ST116B + CM8, dan rizobakteri ST116B dengan daya hambat mencapai 44\% - 61\%. Perlakuan kombinasi rizobakteri tidak menunjukkan persentase daya hambat yang lebih tinggi dibandingkan perlakuan rizobakteri tunggal. Sehingga respon perlakuan kombinasi rizobakteri ST116B + CM8 tidak berbeda nyata dengan perlakuan fungisida metalaksil.

Dari 34 isolat rizobakteri yang diujikan sebanyak 16 isolat rizobakteri dinyatakan mampu dalam melarutkan fosfat, yang ditandai dengan terbentuknya hallo di sekitar media. Sebanyak 8 isolat rizobakteri dari Tripa (TRI), dan 8 isolat dari Gleumpang Minyeuk (GM). Sedangkan 18 lainnya dianggap tidak mampu melarutkan fosfat. Menurut Rodriquez et al. (2004), rizobakteri pelarut fosfat dapat merubah fosfat tidak larut dalam tanah menjadi bentuk yang terlarut dan tersedia bagi tanaman.

Halder et al. (1990) menjelaskan bahwa kemampuan rizobakteri melarutkan kompleks Kalsium fosfat (Ca-P) berkaitan dengan kemampuannya mereduksi $\mathrm{pH}$ di sekitarnya dan produksi asam organik atau proton. Asam organik akan secara langsung melarutkan mineral fosfat hasil perubahan anion $\mathrm{PO}_{4}{ }^{2-}$ oleh anion asam atau dengan mengikat ion $\mathrm{Fe}$ dan $\mathrm{Al}$ yang berasosiasi dengan fosfat.

\section{KESIMPULAN DAN SARAN}

Isolat dengan daya hambat terbaik di jumpai pada isolat GM 8/2, sedangkan pa laju penghambatan pertumbuhan koloni patogen P.palmivora isolat terbaik di jumpai pada TRI 4/7. Dari 34 isolat rizobakteri yang di uji sebanyak 16 isolat rizobakteri dinyatakan mampu dalam melarutkan fosfat sedangkan 18 isolat lainnya dinyatakan tidak mampu dalam melarutkan fosfat

Perlu dilakukan identifikasi terhadap isolat yang memiliki daya hambat tinggi dan diuji pada perkecambahan benih Kakao di Laboratorium dan dilanjutkan pada bibit tanaman Kakao untuk melihat kemampuan rizobakteri sebagai agen antagonis

\section{DAFTAR PUSTAKA}

Aulia, Z., S. Ilyas., C. Budiman., Syamsuddin, D. Manohara. 2017. Peningkatan pertumbuhan tanaman cabai dan pengendalian busuk Phytopthora melalui Biopriming benih dengan rizobakteri asal pertanaman cabai Jawa Timur. Bogor. J. Hort. Indonesia 8(3): 171182. Desember 2017. 
Badan Pusat Statistik Provinsi Aceh. 2013. https://aceh.bps.go.id/dynamic table/2016/04/27/luas-tanam-dan-produksi-kakao-perkebunan-rakyat-menurutkabupaten-kota-2013-2013.html. Diakses tanggal 27-09-2018

Darmono, T. W., I. Jamil dan D. A. Santoso. 2006. Pengembangan penanda molekuler untuk deteksi Phytophthora palmivora pada tanaman kakao. Menara Perkebunan. 74: 86-95.

Direktorat Jendral Perkebunan. 2016. Statistik Perkebunan Indonesia 2015-2017 Kakao. Sekretariat Direktorat Jendral (eds). Jakarta.

Dyah, M., F. N. Rosadiah, S. Ilyas, 2015. Perlakuan benih cabai (Capsicum annuum L.) dengan rizobakteri secara tunggal atau kombinasi dapat mengendalikan Phytophthora capsici dan meningkatkan pertumbuhan tanaman. J. Hort. Indonesia 6(1): 1-10. April 2015

Halder AK, AK. Misra, P. Bhattacharyya, \& PK. Chakrabarty. 1990. Solubilization of rock phosphates by Rhizobium and Bradyrhizobium. J. Gen. Appl. Microbiol. 36:81-92.

Jackson, G.V.H., \& J.G. Wright. (2001). Black pod and canker of cocoa. Eating disorders [leaflet] Pest Advisory No. 7. Plant Protection Service, Secretariat of the Pacific Community.

McMahon, P. \& A. Purwantara (2004). Phytophthora on cocoa. In Drenth A. \& D.I. Guest (eds.). Diversity and Management of Phytophthora in Southeast Asia. ACIAR Monograph No. 114, p.104-115

Rodriguez, H., T. Gonzalez, I. Goire, \& Y. Bahsan. 2004. Gluconic acid production and phosphate solubilaztion by the plant growth-promoting bacterium azopirilium spp. Naturewissenschaften 91:552-555.

Rosmana, A., C. Waniada, M. Junaid and A. Grassa. 2010. Peranan semut Iridomirmex cordatus (Hyminoptera Formicidae) dalam menularkan patogen busuk buah Phytophthora palmivora. Pelita perkebunan. 26(3):169-176.

Sutariati, G.A.K dan A. Wahab. 2010. Isolasi dan Uji Kemampuan Rizobakteri Indigenous sebagai Agensia Pengendalian Hayati Penyakit pada Tanaman cabai. J. Hort.20(1):8695,2010.

Syamsuddin, S. Ilyas, Alfizar dan B. Amin. 2006. Pengembangan Biological Seed Treatment untuk Pengendalian Busuk Phytophthora pada Cabai merah (Capsicum annum L.). Hibah Bersaing XIV Perguruan Tinggi. 